Abstract of the paper presented at ICERI $201710^{\text {th }}$ International Conference of Education, Research and Innovation. Seville 16 th- $18^{\text {th }}$ November 2017

\title{
DESIGN AS A TOOL IN THE MODULE HISTORY OF ARCHITECTURE. LEARNING BY DOING.
}

\author{
Guido Cimadomo' \\ ${ }^{1}$ Universidad de Málaga (Spain)
}

\begin{abstract}
We present the teaching experience of the History of Architecture II module where we introduced a practical exercise aimed at actively learning the theoretical content of the subject: the history of architecture between the fifteenth and eighteenth centuries. The knowledge transmission is based on a preliminary project of a building contextualized in the Renaissance or the Baroque eras.

The results obtained show a greater linkage of students to the subject, a deeper learning of the compositional rules of the studied ages, and greater satisfaction with the dynamics applied, without sacrificing the objectives of explaining the processes in the environment of the society of the time and its direct relationship with the present. We demonstrate the need to adapt teaching methodologies to the generational changes of the students in the 21st century.
\end{abstract}

